Article

\title{
Effects of Human Activities on Hydrological Components in the Yiluo River Basin in Middle Yellow River
}

\author{
Xiujie Wang ${ }^{1}$, Pengfei Zhang ${ }^{1,2}$, Lüliu Liu ${ }^{3, *}$, Dandan $\mathrm{Li}^{1}$ and Yanpeng Wang ${ }^{1}$ \\ 1 State Key Laboratory of Hydraulic Engineering Simulation and Safety, Tianjin University, \\ Tianjin 300350, China; Wangxiujie@tju.edu.cn (X.W.); m18763822967@163.com (P.Z.); \\ 18832012027@163.com (D.L.); wangyanpeng0512@163.com (Y.W.) \\ 2 Tianjin University Frontier Technology Research Institute, No.1 Xinxing Road, Wuqing Development Area, \\ Wuqing District, Tianjin 301700, China \\ 3 National Climate Center, China Meteorological Administration, Beijing 100081, China \\ * Correspondence: liull@cma.gov.cn; Tel.: +86-10-58995906
}

Received: 4 March 2019; Accepted: 29 March 2019; Published: 3 April 2019

\begin{abstract}
Land use and land cover change (LUCC) and water resource utilization behavior and policy (WRUBAP) affect the hydrological cycle in different ways. Their effects on streamflow and hydrological balance components were analyzed in the Yiluo River Basin using the delta method and the Soil and Water Assessment Tool (SWAT). The multivariable (runoff and actual evapotranspiration) calibration and validation method was used to reduce model uncertainty. LUCC impact on hydrological balance components (1976-2015) was evaluated through comparison of simulated paired land use scenarios. WRUBAP impact on runoff was assessed by comparing natural (simulated) and observed runoff. It showed that urban area reduction led to decreased groundwater, but increased surface runoff and increased water area led to increased evaporation. LUCC impact on annual runoff was found limited; for instance, the difference under the paired scenarios was $<1 \mathrm{~mm}$. Observed runoff was 34.7-144.1\% greater than natural runoff during November-June because of WRUBAP. The effect of WRUBAP on wet season runoff regulation was limited before the completion of the Guxian Reservoir, whereas WRUBAP caused a reduction in natural runoff of 21.6-35.0\% during the wet season (July-October) after its completion. The results suggest that WRUBAP has greater influence than LUCC on runoff in the Yiluo River Basin. Based on existing drought mitigation measures, interbasin water transfer measures and deep groundwater exploitation could reduce the potential for drought attributable to predicted future climate extremes. In addition to reservoir regulation, conversion of farmland to forestry in the upstream watershed could also reduce flood risk.
\end{abstract}

Keywords: changes in hydrological components; effects of human activities; LUCC; WRUBAP; Yiluo River

\section{Introduction}

The climate and human activities are two factors that can affect the hydrological cycle in different ways. Climate change alters hydrological systems by inducing both spatiotemporal variations of regional precipitation and changes in temperature [1-3]. Compared with climate change, human activities are more controllable; thus, alteration of human activities constitutes the principal measure for dealing with the potential impacts of climate change on hydrological systems. With recent developments of society and technology, human activities have gradually increased and their consequential impacts on the hydrological cycle on different spatiotemporal scales, such as river basins, have become widely recognized. In general, human activities in river basins can be divided into land use and land cover 
change (LUCC), e.g., vegetation degradation, deforestation, and urbanization, and water resource utilization behavior and policy (WRUBAP), e.g., agricultural irrigation [4], reservoir regulation [5-7], deep groundwater extraction, and interbasin water diversion.

Numerous studies have shown that LUCC can have considerable impact on watershed hydrology in terms of water quantity and water quality. For example, vegetation degradation causes decline in the water storage capacity, which ultimately causes changes in the hydrological balance components (e.g., evapotranspiration, infiltration, and baseflow), or vice versa [8,9]. Moreover, changes in surface albedo, surface aerodynamic roughness, leaf area, and rooting depth caused by changing land use can influence the hydrological cycle via different processes. Land use conflicts have impacts on concentration or yield of nitrates, phosphorus, and sulphates, etc. in both surface water and ground water [10-12]. Hence, understanding the hydrological response of a watershed to LUCC constitutes an important step toward sustainable water resources management. Reasonable WRUBAP is another focus of global attention, particularly in semiarid and subhumid agricultural regions where appropriate watershed management is extremely important in relation to the prevention of droughts/flooding. WRUBAP can affect runoff directly via water intake, water transfer, and reservoir operation and indirectly via other components of the water balance, e.g., groundwater, actual evapotranspiration (ET) and infiltration. The mechanisms via which LUCC and WRUBAP affect hydrological processes are different. Therefore, it is highly important to separate the impacts of LUCC and WRUBAP for sustainable water resources utility and water management, which could ultimately ensure manageable agricultural development and ecological environment protection [13-15].

The paired catchments approach [16-18], statistical analyses, and other modeling approaches $[19,20]$ are methods commonly adopted to further the understanding of how human activities might influence basin hydrology. The paired catchments approach has certain limitations attributable to the sizes and characteristics of the watersheds. Analyses based on statistical methods represent a data-driven approach and thus are not based on physical processes. Distributed hydrological models are physically based models that have been used widely to simulate hydrological responses to human activities [13,21,22]. The Soil and Water Assessment Tool (SWAT) [23-25], which is one of the models used most commonly in hydrological response studies, can be used to assess the influence of human activities on the hydrological balance. The delta approach is often applied in association with the SWAT both to analyze the impacts of LUCC through comparison of hydrological responses under two different land use scenarios for the same time frame, and to evaluate the impacts of WRUBAP by comparing observed values with simulated values that are considered representative of natural runoff.

The Yiluo River Basin in China is located in a region where a semiarid area borders a subhumid area. It supplies water for an important grain-producing region in Henan Province. Regional agricultural production and food security are frequently threatened by serious flooding and droughts attributable to the monsoon climate. Increasingly severe problems regarding water resources are expected in the future because drier springs and increasingly severe flooding over long return periods ( 25 and 50 years) have been projected under the 1.5 and $2{ }^{\circ} \mathrm{C}$ global warming scenarios [26]. However, changes in regional land use have been detected since the 1990s, e.g., the area of cultivated land has decreased and the area of urbanized land has increased [27]. The effects of such changes in land use on hydrological processes have been investigated in previous studies $[21,28]$. For example, the change characteristics of intra-annual and interannual runoff, as well as the relative contributions of climate change and human activities on the decrease in annual runoff, have been explored in earlier research [29,30]. However, their effects on other hydrological variables have rarely been investigated.

This study had two primary objectives: (1) to assess the impacts of LUCC on hydrological balance components, and to determine the relative contributions of individual land use types and (2) to analyze the impact of WRUBAP on streamflow during different periods. The remainder of this paper is organized as follows. Section 2 provides an overview of the study river basin, data, and methods. Section 3 presents the results of both the calibration and validation of the hydrological model and the responses of the hydrological components to LUCC and WRUBAP. The approaches adopted to 
reduce the uncertainty of model parameters and the effects of LUCC and WRUBAP on the hydrological processes are discussed in Section 4. Finally, the main conclusions are summarized in Section 5.

\section{Materials and Method}

\subsection{Study Area}

The Yiluo River Basin $\left(33^{\circ}-35^{\circ} \mathrm{N}, 109^{\circ}-113^{\circ} \mathrm{E}\right.$ ) covers an area of around $18,563 \mathrm{~km}^{2}$ (Figure 1). The river, which is $449 \mathrm{~km}$ long, runs from Shaanxi Province through Henan Province and into the Yellow River in the city of Luoyang. The Heishiguan hydrological station is located at the outlet of the Yiluo River in the northeast of the basin. The Yiluo River has two principal tributaries: the Yihe River and the Luohe River, on each of which is a large reservoir. The Lushun Reservoir, which is located in the middle reaches of the Yihe River, was completed in 1965. The Guxian Reservoir, located in the middle reaches of the Luohe River, was completed in 1994. There are ten types of soil within the Yiluo River watershed: Acrisols, Alisols, Andosols, Arenosols, Anthrosols, Cambisols, Fluvisols, Gleysols, Solonchaks, and Vertiaols (Figure 2). The major land use classes of the region are cultivation (AGRR), barren (BARR), forest (FRST), grassland (RNGE), urban (URBN), and water (WATR) (Figure 3).

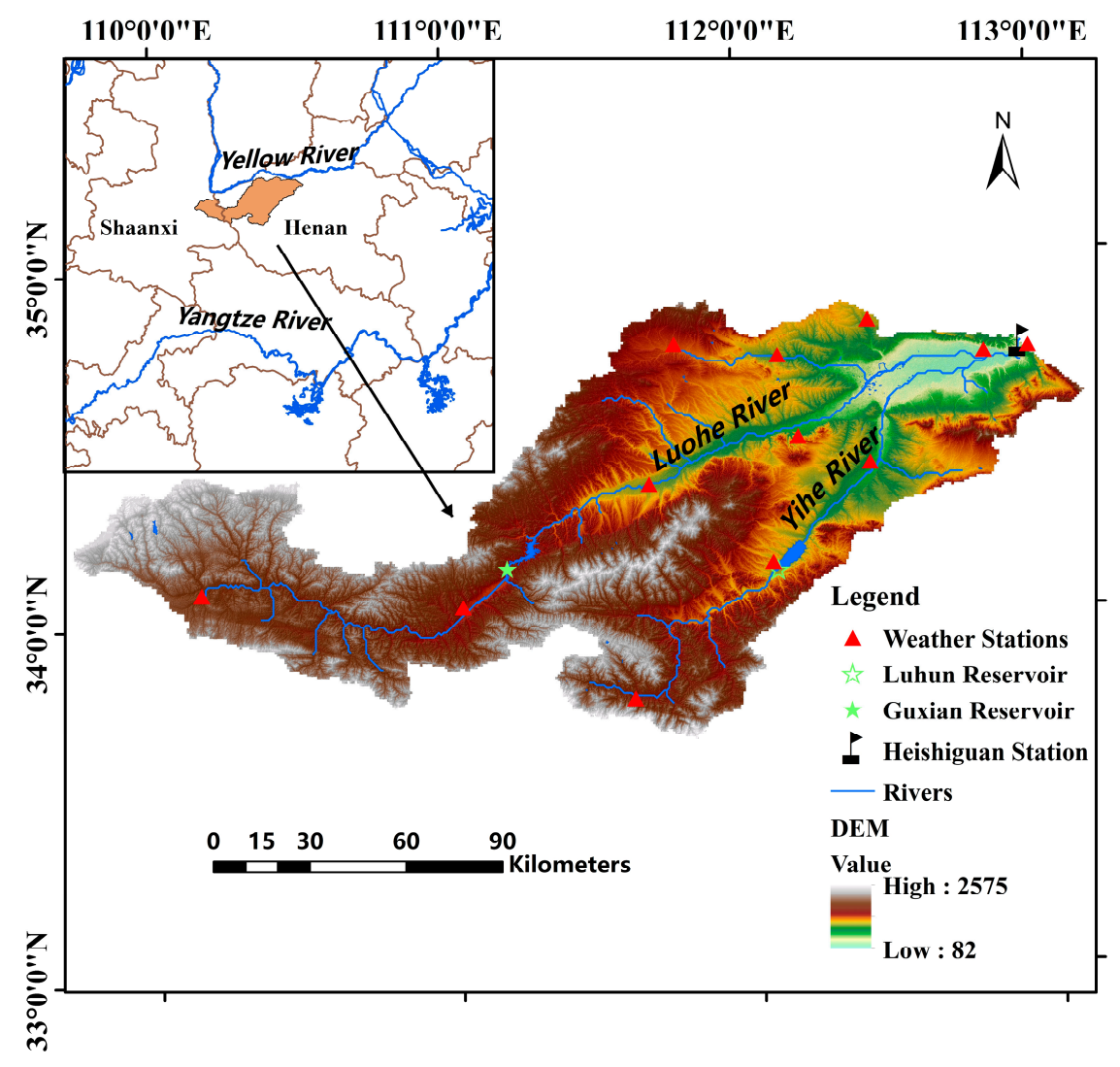

Figure 1. Study area with weather stations, reservoirs, and watershed outlets.

Dominated by a typical continental monsoon climate, precipitation is concentrated in the wet season, and about $60 \%$ of the total precipitation falls during June-September [30]. The annual mean temperature is about $12{ }^{\circ} \mathrm{C}$, and the annual averaged precipitation is in the range $414-1066 \mathrm{~mm}$ (1960-2016). The fluctuation of precipitation causes corresponding changes in the hydrological components. The main source of water supply in the basin is local surface runoff, shallow groundwater and deep groundwater. During the 1980s, local surface runoff accounted for approximately 58-69\% of the total. Local surface runoff is lower in dry years than in normal years, while water demand increases in dry years because of the requirements of agriculture; consequently, such conditions lead to water shortages [31]. Generally, water consumption increases with socioeconomic development and 
an increasing tendency has been observed during the past 20 years in China from Water Resources Bulletins from 1997-2017 (www.mwr.gov.cn).

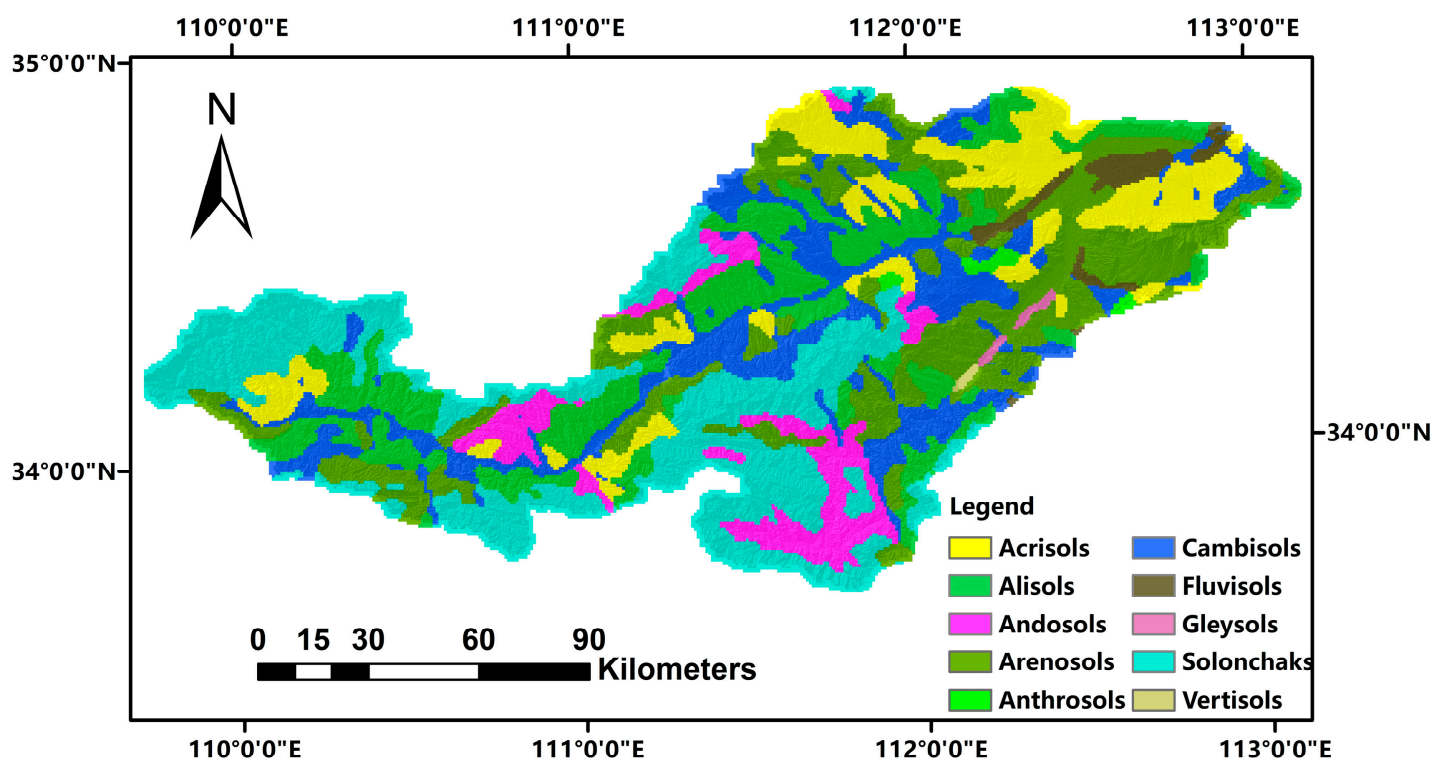

Figure 2. Soil types within the study area.

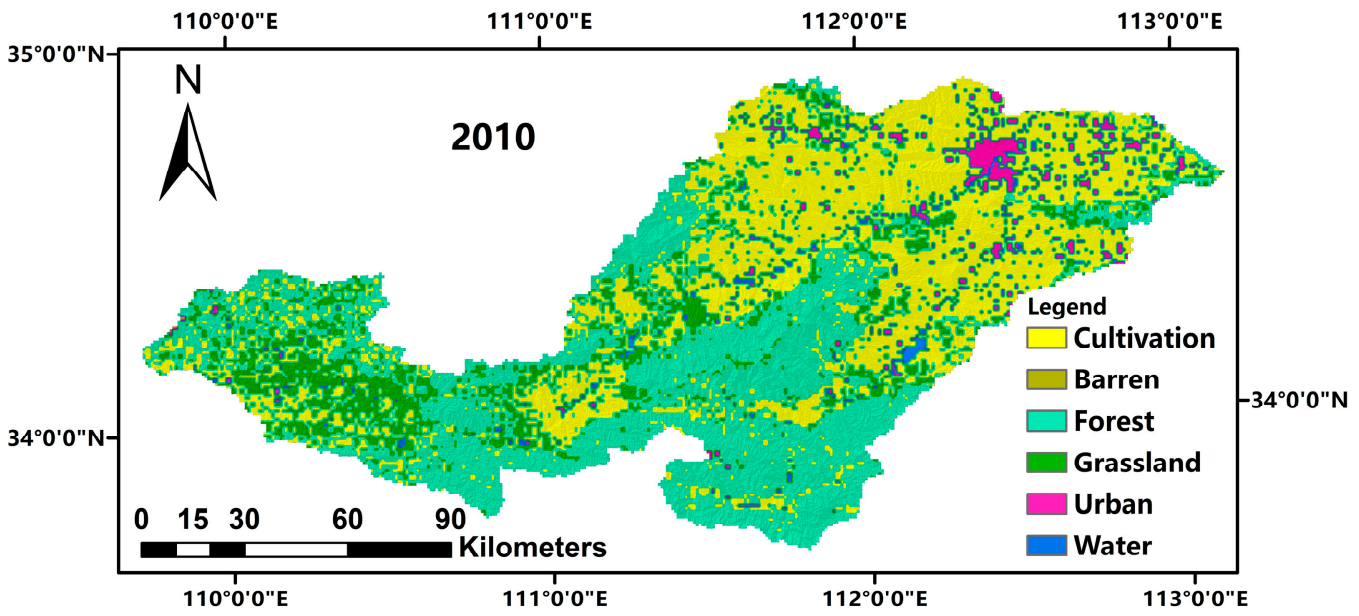

Figure 3. Map of land use maps in 2010 in the Yiluo River Basin (maps for 1980, 1990, and 2000 not shown).

\subsection{Dataset}

A digital elevation model (DEM) maps of soil types and properties, LUCC, meteorological variables, and river discharge data were used in this study. The digital elevation model with 90-m resolution was obtained from the Geospatial Data Cloud of China (http://www.gscloud.cn). The LUCC maps with 1-km resolution for 1980, 1990, 2000, and 2010 were acquired from the Resource and Environment Data Cloud Platform (http://www.resdc.cn). These were used to analyze the changes in land use and to investigate the effects of such changes on the water balance. Soil maps with 1-km resolution were obtained from the Harmonized World Soil Database v1.1 (http://www.fao.org/soils-portal/soil-survey/en). Soil parameters used in the hydrological model were estimated using the Soil-Plant-Air-Water budgeting tool.

Daily minimum temperature, maximum temperature, precipitation, relative humidity, wind speed, and sunshine duration at 12 meteorological stations and daily evaporation at the Guxian hydrological station during 1969-2015 were obtained from the National Meteorological Information Center of the China Meteorological Administration, as shown in Figure 1. Evaporation was monitored using E601B pan. 
Monthly data of observed streamflow through the Heishiguan hydrological station during 1971-2015 were obtained from the Hydrological Yearbook of the Yellow River. These data were used both to calibrate and validate the hydrological model and to analyze the effects of WRUBAP on runoff.

\subsection{Hydrological Modeling}

\subsubsection{Model Introduction}

SWAT $[23,32]$ is a semidistributed hydrological model that is used widely to simulate the effects of varying soils, land use, and management practices on hydrological conditions, sediment loading, and contamination on the basin scale $[32,33]$. This model was applied in this study to the Yiluo River Basin to assess the impacts of LUCC and WRUBAP on hydrological balance components: surface runoff, evapotranspiration, return flow, and lateral flow. The daily water-balance equation can be expressed as follows:

$$
S W_{t}=S W_{0}+\sum_{i=1}^{t}\left(R_{\text {day }}-Q_{\text {surf }}-E T-W_{\text {seep }}-Q_{g w}\right)
$$

where $S W_{t}$ is the final soil moisture content on day $t(\mathrm{~mm}), S W_{0}$ is the initial soil moisture content $(\mathrm{mm})$, $R_{\text {day }}$ is the amount of precipitation on day $i(\mathrm{~mm}), Q_{\text {surf }}$ is the amount of surface runoff on day $i(\mathrm{~mm}), E T$ is the amount of actual evapotranspiration on day $i(\mathrm{~mm}), W_{\text {seep }}$ is the amount of water transferred from the soil profile into the gas zone on day $i(\mathrm{~mm})$, and $Q_{g w}$ is the return flow of day $i(\mathrm{~mm})$.

\subsubsection{Model Setup}

The Yiluo River Basin was divided into 29 sub-basins (Figure 4) and the hydrological response units were based on the land uses, soil types, and slope classes. The modified Soil Conservation Service Curve Number method [34,35], Penman-Monteith method [36,37], and Muskingum routing method were used to simulate the hydrological components.

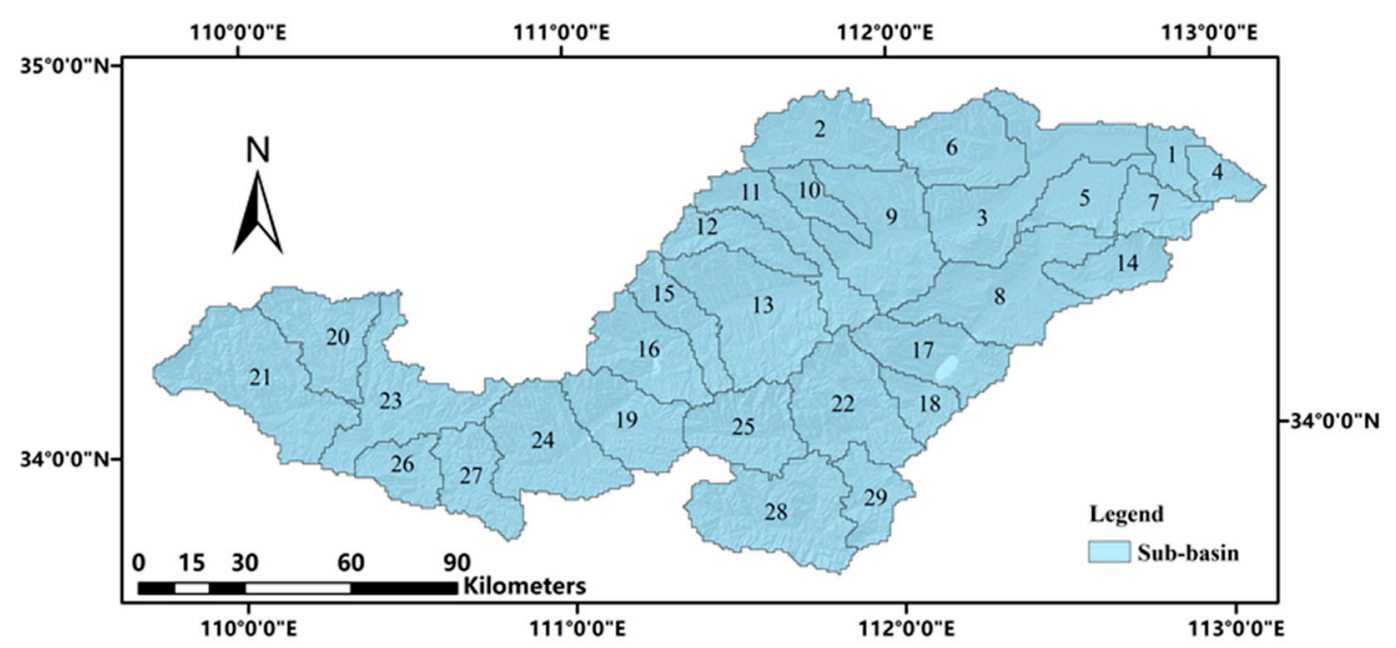

Figure 4. Sub-basins within the study area.

\subsubsection{SWAT Calibration and Validation}

The SWAT model was calibrated using observed monthly runoff and evaporation data series from 1971-1982, and it was validated using monthly historical data from 1983-1985. The 1985 cutoff date was based on the recognition that natural runoff has been changed by human activities since 1986, because a change point in the annual runoff series was detected around 1986, whereas no change point was observed in the annual precipitation series [30].

To reduce model parameter uncertainty and equifinality, the multivariable (runoff and actual evapotranspiration) calibration and validation method (MCVM) was used in this study. Parameters were auto-calibrated using Particle Swarm Optimization (PSO) [38] in the SWAT-CUP (SWAT Calibration 
and Uncertainty Programs) package [39], based on monthly observed discharge through the Heishiguan hydrological station and the set of 20 initial sensitive parameters listed in Table 1 . The initial two years of the simulated outputs were used as a warm-up period [40]. After autocalibration, the performance of ET was improved further by manual adjustment of EPCO (Plant uptake compensation factor) and ESCO (Soil evaporation compensation factor), which are parameters related to soil evaporation and plant transpiration [41]. The formula for calculation of ET is as follows:

$$
E T=K \times E T_{\text {pan }}
$$

where $E T$ is the actual evapotranspiration $(\mathrm{mm}), E T_{\text {pan }}$ is the observed evaporation monitored using an E601B pan and $K$ is a conversion coefficient of evaporation, the value of which is 0.81 according to [42].

Three indices including the Nash-Sutcliffe efficiency (NSE) [43], coefficient of determination $\left(R^{2}\right)$, and percent bias (PBIAS) were used to evaluate the model's performance. The performance of the SWAT model can be judged satisfactory if $R^{2}$ and NSE are both $>0.5$ and PBIAS is $< \pm 25 \%$ [ 44 ].

$$
\begin{aligned}
& N S E=1-\frac{\sum_{i=1}^{n}\left(Q_{i}^{s i m}-Q_{i}{ }^{o b s}\right)^{2}}{\sum_{i=1}^{n}\left(Q_{i}^{o b s}-\overline{Q^{o b s}}\right)^{2}} \\
& R^{2}=\frac{\left[\sum_{i=1}^{n}\left(Q_{i}^{o b s}-\overline{Q^{o b s}}\right)\left(Q_{i}{ }^{s i m}-\overline{Q^{s i m}}\right)\right]^{2}}{\sum_{i=1}^{n}\left(Q_{i}{ }^{o b s}-\overline{Q^{o b s}}\right)^{2} \sum_{i=1}^{n}\left(Q_{i}{ }^{s i m}-\overline{Q^{s i m}}\right)^{2}} \\
& \text { PBIAS }=\frac{\sum_{i=1}^{n}\left(Q_{i}{ }^{\text {obs }}-Q_{i}{ }^{\text {sim }}\right) \times 100}{\sum_{i=1}^{n}\left(Q_{i}{ }^{\text {obs }}\right)}
\end{aligned}
$$

\begin{tabular}{|c|c|c|c|}
\hline Parameters & Description & Range & Value \\
\hline a_CN2 & Curve number & \pm 20 & -10.65 \\
\hline v_GWQMN & $\begin{array}{l}\text { Threshold depth of water in the shallow aquifer required for return flow to } \\
\text { occur (mm) }\end{array}$ & $50-100$ & 59.68 \\
\hline v_GW_REVAP & "Revap" coefficient & $0-0.2$ & 0.22 \\
\hline v_EPCO* & Plant uptake compensation factor & $0.01-1$ & 0.47 \\
\hline v_CH_N2 & Manning's " $\mathrm{n}$ " value for the main channel & $0-0.3$ & 0.01 \\
\hline v_CH_K2 & Effective hydraulic conductivity in main channel $(\mathrm{mm} / \mathrm{h})$ & $0-180$ & 219.56 \\
\hline r_SOL_AWC(1) & Available water capacity of the soil layer & $\pm 100 \%$ & $-21.10 \%$ \\
\hline r_SOL_K(1) & Saturated hydraulic conductivity $(\mathrm{mm} / \mathrm{h})$ & $\pm 100 \%$ & $-66.74 \%$ \\
\hline v_ALPHA_BF & Base-flow recession constant & $0.1-0.8$ & 0.67 \\
\hline v_RCHRG_DP & Deep aquifer percolation fraction & $0.1-0.8$ & 0.32 \\
\hline v_REVAPMN & Threshold depth of water in the shallow aquifer for "Revap" to occur (mm) & $50-450$ & 174.59 \\
\hline v_CANMX & Maximum canopy storage & 3 & 12.55 \\
\hline v_SURLAG & surface runoff lag time & $1-24$ & 31.47 \\
\hline V_ALPHA_BNK & Baseflow alpha factor for bank storage & $0.1-0.8$ & 0.60 \\
\hline v_SFTMP & Snowfall temperature $\left({ }^{\circ} \mathrm{C}\right)$ & \pm 5 & 0.51 \\
\hline v_SMTMP & Snowmelt base temperature $\left({ }^{\circ} \mathrm{C}\right)$ & \pm 5 & 2.42 \\
\hline v_SMFMX & Melt factor for snow on June $21\left(\mathrm{~mm} \mathrm{H}_{2} \mathrm{O} /{ }^{\circ} \mathrm{C}\right.$-day $)$ & $0-10$ & 4.30 \\
\hline v_SMFMN & Melt factor for snow on December $21\left(\mathrm{~mm} \mathrm{H}_{2} \mathrm{O} /{ }^{\circ} \mathrm{C}\right.$-day $)$ & $0-10$ & 1.33 \\
\hline V_TIMP & Snow pack temperature lag factor & $0.1-0.8$ & 0.83 \\
\hline v_ESCO* & Soil evaporation compensation coefficient & $0.01-1$ & 0.54 \\
\hline
\end{tabular}

where $n$ is the total number of sample pairs, $Q_{i}{ }^{\text {obs }}$ is the observed value, $\overline{Q^{\text {obs }}}$ is the mean of the observed values, $Q_{i}{ }^{\text {sim }}$ is the simulated value and $\overline{Q^{\operatorname{sim}}}$ is the mean of the simulated values.

Table 1. Optimal parameter values calibrated for the Yiluo River Basin.

$\mathrm{v}$ _ _ means the current parameter value is to be replaced by a given value, a _ means a given value is added to the current parameter value, and $r_{\text {_ }}$ means the current parameter value is multiplied by $\left(1+\right.$ a given value). ${ }^{*}$ means the optimal parameter value was finally determined by manual calibration based on actual evaporation (ET). 


\subsection{Evaluation Effects of LUCC and WRUBAP}

The delta approach was applied to assess the impact of LUCC. First, four scenarios (S1, S2, S3, and S4) were defined based on available LUCC data for 1980, 1990, 2000, and 2010 and the contemporaneous climate, which was taken as the ten-year mean during 1976-1985, 1986-1995, 1996-2005, and 2006-2015, respectively. Among them, S1 was set as the baseline period. The runoff simulated under the four actual LUCC scenarios approximately emulated the natural runoff on the monthly scale. Then, three LUCC scenarios (S2* ${ }^{*} 3^{*}$, and $\mathrm{S4}^{*}$ ) were defined using the same climate series as in S2, $\mathrm{S} 3$, and S4 and LUCC data for 1980 (Table 2). The effects of LUCC were evaluated by comparing S2 against S2*, S3 against $\mathrm{S}^{*}$, and $\mathrm{S} 4$ against $\mathrm{S}^{*}$ using the following Equation:

$$
\text { Deviation }_{\text {lucc }}=W_{\text {sim }}^{S}-W_{\text {sim }}^{S *}
$$

where Deviation lucc $_{\text {is }}$ ise change of the water balance term under the actual scenario relative to the baseline scenario, $W_{\text {sim }}^{S *}$ is the water balance term under the baseline scenario and $W_{\text {sim }}^{S}$ is the water balance term under the actual scenario.

The effects of WRUBAP on river runoff were evaluated by comparing the simultaneously simulated and observed runoff under each of the S1, S2, S3, and S4 scenarios using the following Equation:

$$
\text { Deviation }_{\text {WRUBAP }}=Q_{\text {sim }}-Q_{o b s}
$$

where Deviation ${ }_{\text {WRUBAP }}$ is the difference between the simulated and observed runoff, $Q_{\text {sim }}$ is the simulated runoff under the actual LUCC and $Q_{o b s}$ is the observed runoff.

Table 2. Scenario setting based on climate and land use and land cover change (LUCC).

\begin{tabular}{cccc}
\hline Scenarios & & Climate Data & LUCC Data \\
\hline Baseline & S1 & $1976-1985$ & 1980 \\
\hline \multirow{3}{*}{ Actual LUCC } & S2 & $1986-1995$ & 1990 \\
& S3 & $1996-2005$ & 2000 \\
& S4 & $2006-2015$ & 2010 \\
Baseline LUCC & S2* & $1986-1995$ & 1980 \\
& S3 $^{*}$ & $1996-2005$ & 1980 \\
& S4 $^{*}$ & $2006-2015$ & 1980 \\
\hline
\end{tabular}

\section{Result}

\subsection{Model Calibration and Validation}

The NSE value for monthly runoff during the calibration periods was 0.85 , the $R^{2}$ value was 0.88 and the PBIAS value was 13.37. The NSE for yearly ET during calibration was 0.84 , the $R^{2}$ value was 0.87 and the PBIAS value was -1.36 , indicating good agreement between the monthly simulated values and the observation values during the calibration period. Moreover, satisfactory results were also obtained during the validation, with NSE, $R^{2}$, and PBIAS values of $0.72,0.75$, and 12.01 , respectively, in the runoff validation and $0.80,0.81$, and -6.06 , respectively, in the $E T$ validation. The results of the peak value were reasonably accurate, but the base flow was underestimated (Figure 5a). Similarly, the peaks of $E T>150 \mathrm{~mm} / \mathrm{month}$ were also underestimated (Figure 5b). Overall, the simulations for water discharge and $E T$ indicated satisfactory agreement between the observed and simulated values; thus, the parameters were considered credible and the model deemed suitable for simulating the natural water balance of the Yiluo River Basin. 

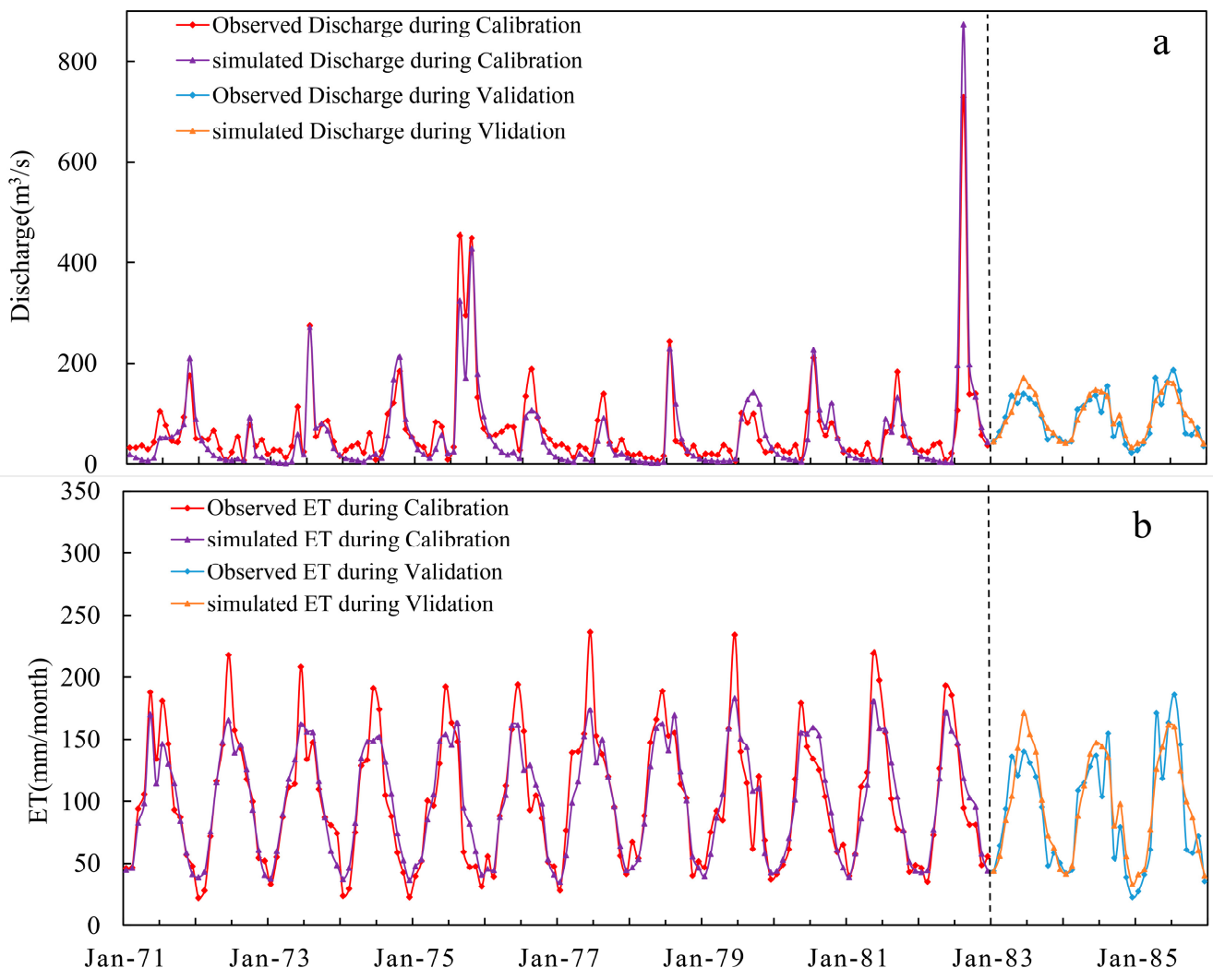

Figure 5. Simulated and observed monthly (a) discharge and (b) actual evapotranspiration (ET) during calibration period (1971-1982) and validation period (1983-1985).

\subsection{Analysis of LUCC}

The areas of AGRR, FRST, RNGE, URBN, WATR, and BARR in 1980, 1990, 2000, and 2010, as well as their changes relative to 1980, are listed in Table 3. In 1980, the main land use types were AGRR, RNGE, and FRST, which accounted for $94.8 \%$ of the total watershed area. Through urban centralization and the "Returning farmland to grass" policy, sporadic areas of URBN were converted to AGRR, while some AGRR land was converted to RNGE during 1980-1990. The RNGE area increased by $115 \mathrm{~km}^{2}$ from $3038 \mathrm{~km}^{2}$, but the area of AGRR, URBN, and FRST decreased by 59, 48, and $7 \mathrm{~km}^{2}$, respectively, in 1990 relative to 1980. After 1990, because of reservoir construction and enhanced urbanization, the areas of WATR and URBN both increased, while the areas of the other four main land use types decreased. The WATR area increased by $35 \mathrm{~km}^{2}$ in 2000 and by $38 \mathrm{~km}^{2}$ in 2010, URBN increased by $121 \mathrm{~km}^{2}$ in 2000 and by $187 \mathrm{~km}^{2}$ in 2010, but AGRR decreased by 72 and $148 \mathrm{~km}^{2}$ in 2000 and 2010, respectively, relative to 1980 .

Table 3. LUCC in 1980, 1990, 2000, and 2010 relative to 1980.

\begin{tabular}{ccccccc}
\hline \multirow{2}{*}{ LUCC } & \multicolumn{7}{c}{ Area(km $\mathbf{k m}^{\mathbf{}} \mathbf{}$} \\
\cline { 2 - 7 } & AGRR & FRST & RNGE & URBN & WATR & BARR \\
\hline 1980 & 8166 & 6481 & 3038 & 664 & 297 & 9 \\
1990 & 8107 & 6474 & 3153 & 616 & 297 & 7 \\
2000 & 8094 & 6459 & 2976 & 785 & 332 & 8 \\
2010 & 8018 & 6469 & 2977 & 851 & 335 & 8 \\
$1990-1980$ & -59 & -7 & 115 & -48 & 0 & -2 \\
$2000-1980$ & -72 & -22 & -62 & 121 & 35 & -1 \\
$2010-1980$ & -148 & -12 & -61 & 187 & 38 & -1 \\
\hline
\end{tabular}




\subsection{Responses of Hydrological Components and Runoff to LUCC}

Table 4 summarizes the annual rainfall, ET, surface runoff (SURQ), return flow (GWQ), and runoff depth (RD) under each scenario and their difference between paired scenarios. Comparatively, the values of ET and GWQ are higher by 0.2 and $0.1 \mathrm{~mm}$ but SURQ and RD are lower by 0.3 and $0.4 \mathrm{~mm}$, respectively, under scenario $\mathrm{S} 2$ relative to $\mathrm{S} 2^{*}$. The values of ET, SURQ, and RD are higher by 1.0, 0.5, and $0.2 \mathrm{~mm}$, respectively, and GWQ is lower by $0.5 \mathrm{~mm}$ under scenario S3 relative to S3*. The values of $E T$ and SURQ are higher by 0.9 and $0.7 \mathrm{~mm}$, respectively, and GWQ is lower by $0.3 \mathrm{~mm}$ under scenario $\mathrm{S} 4$ relative to $S 4^{*}$.

Table 4. Water balance components and the difference between paired scenarios.

\begin{tabular}{cccccc}
\hline Scenario & Rainfall $(\mathbf{m m})$ & $\boldsymbol{E T}(\mathbf{m m})$ & SURQ $(\mathbf{m m})$ & GWQ $(\mathbf{m m})$ & RD $(\mathbf{m m})$ \\
\hline S1 & 698.6 & 574.8 & 60 & 51.9 & 133.4 \\
S2 & 611.4 & 563 & 27.2 & 22.4 & 61.5 \\
S2 & 611.4 & 562.8 & 27.5 & 22.3 & 61.9 \\
S2-S2* & 0 & 0.2 & -0.3 & 0.1 & -0.4 \\
S3 & 669.7 & 562.4 & 53 & 44.7 & 116.7 \\
S3 & 669.7 & 561.4 & 52.5 & 45.2 & 116.5 \\
S3-S3* & 0 & 1.0 & 0.5 & -0.5 & 0.2 \\
S4 & 645.8 & 571.9 & 41.4 & 30.2 & 88.8 \\
S4 & 645.8 & 571 & 40.7 & 30.5 & 88.8 \\
S4-S4 $^{*}$ & 0 & 0.9 & 0.7 & -0.3 & 0 \\
\hline
\end{tabular}

Generally, ET occurs in three forms: vegetation transpiration (VT), soil evaporation (SE), and water evaporation (WE) [45]. In the efficient consumption of ET, vegetation land uses (AGRR, FRST, and RNGE) possess greater VT and SE than URBN land use. The total amount of WE from WATR is much higher than from the other five LUCC types. Under scenario S2, the increase in ET was caused mainly by the reduction of the URBN area and the expansion of RNGE. It also caused a slight decrease of RD. The URBN and RNGE under scenarios S3 and S4 presented an opposite trend to scenario S2 However, the trend of increase in ET was enhanced, which could be explained by the obvious expansion of the WATR area. In addition, plant root systems change the physical properties of soil, improve infiltration and GWQ and ultimately decrease SURQ. This suggests that the expansion of vegetation land uses leads to increase of both GWQ and ET but to decrease of SURQ, which consequently leads to higher water-holding capacity. These effects can be seen under scenario S2 relative to S2*. The effects of URBN expansion are opposite to those of vegetation expansion because URBN does not allow much soil evaporation or water infiltration; thus, most precipitation within an URBN area flows into rivers in the form of SURQ. The continuous urbanization after 1990 in the study area has played a positive role in the increase of SURQ.

\subsection{Response of Runoff to WRUBAP}

This study analyzed the effect of WRUBAP on RD only because of data availability. In this part, the simulated RD under the baseline scenario (S1) and the actual LUCC scenarios (S2, S3, and S4) are assumed to represent natural RD.

Scenario S1 (1976-1985): At Hesihiguan station, the observed monthly runoff under scenario S1 was obviously higher than the natural runoff in the first seven months of the year but lower in the final three months (Figure 6a). The main cause was reservoir regulation performed to meet the needs of agricultural irrigation during April-June. Consistency between the dry season and the irrigation period in the study area requires reservoir regulation. Water storage in the reservoir during October-December in most cases caused the observed runoff to be lower than the natural runoff during this period. To supply crop growth with sufficient water during April-June, the watershed management commission would release reservoir storage. That action resulted in observed runoff $(78.1 \mathrm{~mm})$ being higher than the natural RD $(56.7 \mathrm{~mm})$ during the dry season, and WRUBAP accounted for about $37.7 \%$ of the 
natural RD (Table 5). In addition, because of flood prevention, reservoir storage capacity was reserved by discharging water in the early wet season; therefore, observed runoff was slightly higher than natural runoff during July. Ultimately, the effect of WRUBAP on runoff was reasonably small during the wet season under scenario S1.
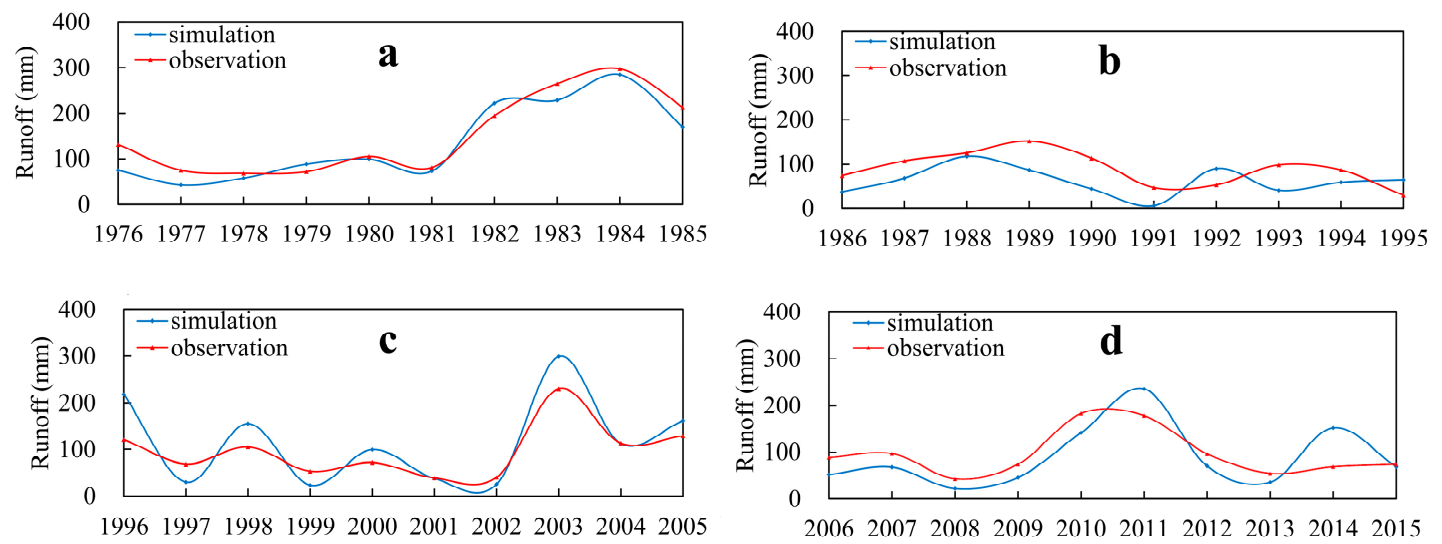

Figure 6. Comparison between the simulated and observed annual runoff values for scenarios (a) S1, (b) S2, (c) S3, and (d) S4.

Table 5. Comparison between the simulated (natural) and observed mean discharge during the dry season and the wet season under scenarios S1, S2, S3, and S4.

\begin{tabular}{cccccc}
\hline \multirow{2}{*}{ Scenario } & Time Frame & \multicolumn{2}{c}{ RD $(\mathbf{m m})$} & $\begin{array}{c}\text { Deviation } \\
(\mathbf{m m})\end{array}$ & $\begin{array}{c}\text { Deviation Rate } \\
\mathbf{( \% )}\end{array}$ \\
\cline { 3 - 4 } & & Simulation & Observation & & 12.2 \\
\multirow{3}{*}{ S1 } & annual & 133.4 & 149.7 & 16.3 & 2.1 \\
& Wet season & 286.8 & 292.7 & 5.9 & 37.7 \\
\hline \multirow{3}{*}{ S2 } & Dry season & 56.7 & 78.1 & 21.4 & 44.1 \\
& annual & 61.5 & 88.6 & 27.1 & -3.1 \\
& Wet season & 125.0 & 121.1 & -3.9 & 144.1 \\
\hline \multirow{3}{*}{ S3 } & Dry season & 29.7 & 72.4 & 42.7 & -16.6 \\
& annual & 116.7 & 97.3 & -19.4 & -35.0 \\
& Wet season & 254.2 & 165.2 & -89.0 & 34.7 \\
\hline \multirow{2}{*}{ S4 } & Dry season & 47.0 & 63.3 & 16.3 & 7.5 \\
& annual & 88.8 & 95.4 & 6.6 & -21.6 \\
& Wet season & 185.7 & 145.5 & -40.1 & 72.6 \\
\hline
\end{tabular}

Notes: Deviation $=$ observation - simulation; Deviation rate $=$ Deviation/simulation $\times 100 \%$. Dry season: January-June, November and December, Wet season: July-October.

Scenario S2 (1986-1995): Observed annual runoff under scenario S2 was greater than natural runoff in most years except 1992 and 1995, as shown in Figure 6b. Moreover, the observed monthly runoff was greater than the natural runoff in both the dry season and the early wet season (July), as shown in Figure $7 \mathrm{~b}$. This might be attributable to reservoir regulation and to irrigation through the extraction of deep groundwater. Storing water in the reservoir upstream of the Heishiguan station during August and September led to the observed runoff being smaller than the natural runoff. Conversely, discharging water during the dry season led to the observed runoff being greater than the natural runoff. The extraction of deep groundwater to supply irrigation increased the base flow, which ultimately led to the observed RD $(72.4 \mathrm{~mm})$ being higher by $144.1 \%$ than the natural RD $(29.7 \mathrm{~mm})$ during the dry season (Table 5). Consequently, the impact of WRUBAP on runoff in the wet season under scenario S2 was reasonably small. 


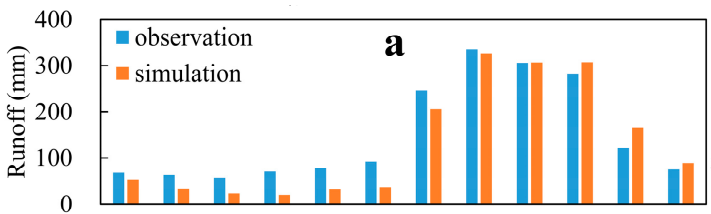

Jan Feb Mar Apr May Jun Jul Aug Sep Oct Nov Dec

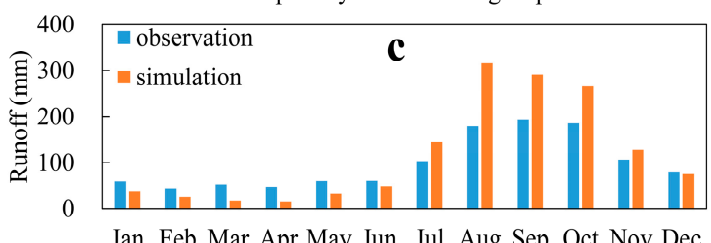

Jan Feb Mar Apr May Jun Jul Aug Sep Oct Nov Dec

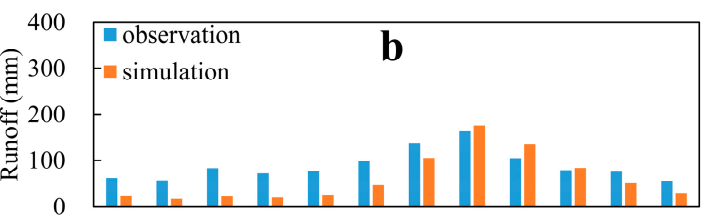

Jan Feb Mar Apr May Jun Jul Aug Sep Oct Nov Dec

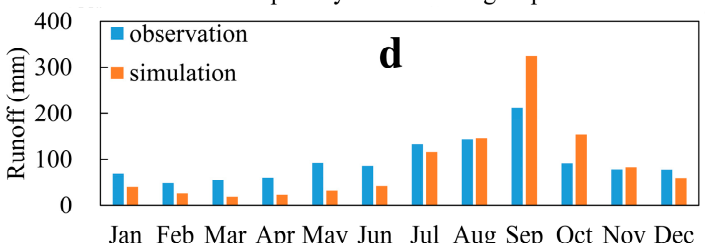

Figure 7. Simulated and observed monthly runoff under scenarios (a) S1, (b) S2, (c) S3, and (d) S4.

Scenario S3 (1996-2005): As shown in Figure 6c, annual observed runoff was smaller in the relatively wet years $(1996,1998,2000,2003$, and 2005) but greater in the relatively dry years $(1997,1999$, and 2002) than natural runoff. This might be due to stronger interannual water resource management than under scenarios S1 and S2 to prevent floods during the wet years and to prevent droughts during the dry years. The effects of regulation can also be seen in Figure $7 \mathrm{c}$ and Table 5. The observed RD $(165.2 \mathrm{~mm})$ was smaller by $35.0 \%$ than the natural RD $(254.2 \mathrm{~mm})$ during the wet season, but the observed RD $(63.3 \mathrm{~mm})$ was higher by $34.7 \%$ than the natural $\mathrm{RD}(47.0 \mathrm{~mm})$ during the dry season. It indicates that the effect of WRUBAP on runoff under scenario S3 was enhanced during the wet season.

Scenario S4 (2006-2015): Similar to scenario S3, observed annual runoff was smaller in relatively wet years but greater in relatively dry years (Figure 7d) than natural runoff. Natural annual RD under scenario S3 $(116.7 \mathrm{~mm})$ was higher by $27.9 \mathrm{~mm}$ than under scenario S4 $(88.8 \mathrm{~mm})$. However, annual observed RD under scenario S3 $(97.3 \mathrm{~mm}$ ) was almost equal to that under scenario S4 (95.4 $\mathrm{mm}$ ) (Table 5). Observed monthly RD $(145.5 \mathrm{~mm})$ was lower by $21.6 \%$ than natural RD $(185.7 \mathrm{~mm})$ during the wet season but higher by $34.7 \%$ than natural RD $(40.8 \mathrm{~mm})$ during the wet season. It suggests the effect of WRUBAP under scenario $S 4$ alleviates the unbalanced temporal distribution of the water resource.

\section{Discussion}

Parameter uncertainty and equifinality can influence numerical model performance. At the basin scale, multiobjective optimization algorithms [46-48], multiperiod parameterization [49,50], and the MCVM are methods commonly adopted to reduce uncertainty. Generally, the MCVM is based on observed discharge at multiple hydrological stations. In this study, the two variables of discharge and $E T$ were used to calibrate/validate a numerical model to reduce parameter uncertainty and to improve ET performance. Although human activities, especially WRUBAP, were not accounted for in the calibration and validation of SWAT model, the model performance is satisfactory. Simulation, not observation, during the baseline period was compared with other scenarios to explore the effects of human activities.

In this study, the CN value of FRST was lower than other five land use types, which indicates that FRST has a stronger ability of water storage and is likely to reduce more SURQ. It has previously been found that Grassland and cultivation have similar influences on hydrological balance components in this area [14], and the mutual transformation between them has little effect on water yield within the Yiluo River basin. Compared with herbaceous plants (grassland and cultivation), woody plants have more developed root systems and canopies; thus, conversion of herbaceous plants into forests would enhance the capacity of catchment to conserves soil and water, and reduce water yield [51,52], which consequently affects the yield of phosphorus and nitrates $[12,53]$. Considering that the upstream regions of the Yiluo River Basin are mountainous areas and are not the main crop region, returning farmland to forests is conducive to preventing land degradation, increasing infiltration, and thus 
reducing flood risk $[54,55]$. However, quantitative analysis has not been performed in this study. This will be carried out in further study.

Hydrological changes have important impacts on the local use of natural water [56]. However, compared with LUCC, WRUBAP has more dynamic and greater impact on hydrological processes, particularly in monsoon climate zones. It is noticed that the Guxian Reservoir greatly improved the capacity of runoff regulation in the wet season. Therefore, reservoirs could be used to respond to climate variety, which increases runoff in the dry season while decreasing runoff in the wet season. A recent study made similar conclusions, indicating that large and small reservoirs can have equally large effects on runoff [57].

\section{Conclusions}

In this study, the SWAT model and the MCVM were used to assess the impact of human activities (LUCC and WRUBAP) on the catchment hydrology of the Yiluo River Basin during 1976-2015. Based on the analysis, the following conclusions were drawn.

(1) Increased areas of urban land and decreased areas of vegetation land resulted in decrease of both groundwater and ET, but increase of average surface runoff, and vice versa. Although the expansion of water areas resulted in an increase of ET, it had little effect on groundwater and surface runoff in the studied region. It was found that LUCC had limited effect on annual runoff, i.e., the difference in annual runoff under paired scenarios was $<1 \mathrm{~mm}$.

(2) WRUBAP has greater influence than LUCC on runoff. Affected by WRUBAP, the observed $\mathrm{RD}$ varied in the range $63.3-78.1 \mathrm{~mm}$ during the dry season, which was $34.7 \%-144.1 \%$ greater than natural RD. After completion of the Guxian Reservoir, the observed RD was found to be $21.6 \%-35.0 \%$ less than natural RD.

(3) Returning farmland to forestry in upstream regions and adopting interbasin water transfer and deep groundwater exploitation could be useful supplementary measures for reducing the risk of extreme hydrological events in the future.

Author Contributions: Conceptualization, X.W. and L.L; data curation, P.Z.; Methodology L.L. and P.Z.; Resources, X.W. and L.L.; Software, P.Z. and L.L.; Supervision, Z.W. and L.L; Writing-Original Draft, L.L., X.W. and P.Z.; Manuscript revision/review D.L. and Y.W.

Funding: This study was supported by the National Key R\&D Program of China (Grant Nos. 2017YFA0605004, 2016YFE0102400, and 2018YFC1508403), and National Natural Science Foundation of China (51579173).

Acknowledgments: The authors wish to acknowledge the assistance of all the editors and reviewers. We thank James Buxton MSc from Liwen Bianji, Edanz Group China (www.liwenbianji.cn./ac), for editing the English text of this manuscript.

Conflicts of Interest: The authors declare no conflict of interest.

\section{References}

1. Woldesenbet, T.A.; Elagib, N.A.; Ribbe, L.; Heinrich, J. Catchment response to climate and land use changes in the Upper Blue Nile sub-basins, Ethiopia. Sci. Total Environ. 2018, 644, 193-206. [CrossRef] [PubMed]

2. Silva, V.d.P.R.; Campos, J.H.; Silva, M.T.; Azevedo, P.V. Impact of global warming on cowpea bean cultivation in northeastern Brazil. Agric. Water Manag. 2010, 97, 1760-1768. [CrossRef]

3. Pereira, D.d.R.; Martinez, M.A.; da Silva, D.D.; Pruski, F.F. Hydrological simulation in a basin of typical tropical climate and soil using the SWAT Model Part II: Simulation of hydrological variables and soil use scenarios. J. Hydrol. Reg. Stud. 2016, 5, 149-163. [CrossRef]

4. Zhang, X.; Ren, L.; Kong, X. Estimating spatiotemporal variability and sustainability of shallow groundwater in a well-irrigated plain of the Haihe River basin using SWAT model. J. Hydrol. 2016, 541, 1221-1240. [CrossRef]

5. Buytaert, W.; Célleri, R.; De Bièvre, B.; Cisneros, F.; Wyseure, G.; Deckers, J.; Hofstede, R. Human impact on the hydrology of the Andean páramos. Earth Sci. Rev. 2006, 79, 53-72. [CrossRef] 
6. Shen, Z.Y.; Gong, Y.W.; Li, Y.H.; Hong, Q.; Xu, L.; Liu, R.M. A comparison of WEPP and SWAT for modeling soil erosion of the Zhangjiachong Watershed in the Three Gorges Reservoir Area. Agric. Water Manag. 2009, 96, 1435-1442. [CrossRef]

7. Wang, Y.; Zhang, N.; Wang, D.; Wu, J.; Zhang, X. Investigating the impacts of cascade hydropower development on the natural flow regime in the Yangtze River. China Sci. Total Environ. 2018, 624, 1187-1194. [CrossRef] [PubMed]

8. Descheemaeker, K.; Nyssen, J.; Poesen, J.; Raes, D.; Haile, M.; Muys, B.; Deckers, S. Runoff on slopes with restoring vegetation: A case study from the Tigray highlands, Ethiopia. J. Hydrol. 2006, 331, $219-241$. [CrossRef]

9. Pacheco, F.; Varandas, S.G.P.; Fernandes, L.S.; Junior, R.V. Soil losses in rural watersheds with environmental land use conflicts. Sci. Total Environ. 2014, 485, 110-120. [CrossRef]

10. Junior, R.V.; Varandas, S.G.P.; Fernandes, L.S.; Pacheco, F.A.L. Groundwater quality in rural watersheds with environmental land use conflicts. Sci. Total Environ. 2014, 493, 812-827.

11. Junior, R.F.V.; Varandas, S.G.; Pacheco, F.A.; Pereira, V.R.; Santos, C.F.; Cortes, R.M.; Fernandes, L.F.S. Impacts of land use conflicts on riverine ecosystems. Land Use Policy 2015, 43, 48-62. [CrossRef]

12. Pacheco, F.; Santos, R.M.B.; Fernandes, L.S.; Pereira, M.G.; Cortes, R.M.V. Controls and forecasts of nitrate yields in forested watersheds: A view over mainland Portugal. Sci. Total Environ. 2015, 537, 421-440. [CrossRef] [PubMed]

13. Woldesenbet, T.A.; Elagib, N.A.; Ribbe, L.; Heinrich, J. Hydrological responses to land use/cover changes in the source region of the Upper Blue Nile Basin, Ethiopia. Sci. Total Environ. 2017, 575, 724-741. [CrossRef] [PubMed]

14. Li, Y.; Chang, J.; Wang, Y.; Jin, W.; Bai, X. Spatiotemporal responses of runoff to land use change in Wei River Basin. Trans. Chin. Soc. Agric. Eng. 2016, 32, 232-238.

15. Song, W.; Deng, X.; Yuan, Y.; Wang, Z.; Li, Z. Impacts of land-use change on valued ecosystem service in rapidly urbanized North China Plain. Ecol. Model. 2015, 318, 245-253. [CrossRef]

16. Bi, H.; Liu, B.; Wu, J.; Yun, L.; Chen, Z.; Cui, Z. Effects of precipitation and land use on runoff during the past 50 years in a typical watershed in Loess Plateau, China. Int. J. Sediment Res. 2009, 24, 352-364. [CrossRef]

17. Zhang, Y.-K.; Schilling, K. Increasing streamflow and baseflow in Mississippi River since the 1940 s: Effect of land use change. J. Hydrol. 2006, 324, 412-422. [CrossRef]

18. Zeng, S.; Xia, J.; Du, H. Separating the effects of climate change and human activities on runoff over different time scales in the Zhang River basin. Stoch. Environ. Res. Risk Assess. 2014, 28, 401-413. [CrossRef]

19. Christensen, N.S.; Wood, A.W.; Voisin, N.; Lettenmaier, D.P.; Palmer, R.N. The Effects of Climate Change on the Hydrology and Water Resources of the Colorado River Basin. Clim. Chang. 2004, 62, 337-363. [CrossRef]

20. Rostamian, R.; Jaleh, A.; Afyuni, M.; Mousavi, S.F.; Heidarpour, M.; Jalalian, A.; Abbaspour, K.C. Application of a SWAT model for estimating runoff and sediment in two mountainous basins in central Iran. Hydrol. Sci. J. 2008, 53, 977-988. [CrossRef]

21. Liu, Q.; Yang, Z.; Cui, B.; Sun, T. Temporal trends of hydro-climatic variables and runoff response to climatic variability and vegetation changes in the Yiluo River basin, China. Hydrol. Process. Int. J. 2009, 23, 3030-3039. [CrossRef]

22. Wang, Q.; Liu, R.; Men, C.; Guo, L. Application of genetic algorithm to land use optimization for non-point source pollution control based on CLUE-S and SWAT. J. Hydrol. 2018, 560, 86-96. [CrossRef]

23. Kiniry, J.R.; Williams, J.R.; King, K.W. Soil and Water Assessment Tool Theoretical Documentation (Version 2005). Comput. Speech Lang. 2011, 24, 289-306.

24. Douglas-Mankin, K.R.; Srinivasan, R.; Arnold, A.J. Soil and Water Assessment Tool (SWAT) Model: Current Developments and Applications. Trans. ASABE 2010, 53, 1423-1431. [CrossRef]

25. Arnold, J.G.; Fohrer, N. SWAT2000: Current capabilities and research opportunities in applied watershed modelling. Hydrol. Process. 2005, 19, 563-572. [CrossRef]

26. Liu, L.; Xu, H.; Wang, Y.; Jiang, T. Impacts of 1.5 and $2{ }^{\circ} \mathrm{C}$ global warming on water availability and extreme hydrological events in Yiluo and Beijiang River catchments in China. Clim. Chang. 2017, 145, 145-158. [CrossRef]

27. Li, S.; Hu, C.; Wang, H.; Zhang, Z.; Li, X. Pattern Analysis on Land Use/Cover Changes in Yiluo Drainage Basin. Meteorol. Environ. Sci. 2015, 38, 108-113.

28. Wang, W.; Qian, L. Spatial distribution and seasonal variation of evapotranspiration in Yiluo River basin on MODIS data. Resour. Sci. 2012, 34, 1582-1590. 
29. He, R.; Wang, G.; Zhang, J. Impacts of environmental change on runoff in the Yiluohe River Basin of the Middle Yellow River. Res. Soil Water Conserv. 2007, 2, 297-301.

30. Liu, X.; Dai, X.; Zhong, Y.; Li, J.; Wang, P. Analysis of changes in the relationship between precipitation and streamflow in the Yiluo River, China. Theor. Appl. Climatol. 2013, 114, 183-191. [CrossRef]

31. Guo, J.; Zheng, J. Yiluo River Basin Annals; China Science \& Technology Press: Henan, China, 1995.

32. Neitsch, S.L. Soil and Water Assessment Tool Theoretical Documentation Version 2009; Texas Water Resources Institute: Texas, TX, USA, 2011.

33. Arnold, J.G.; Srinivasan, R.; Muttiah, R.S.; Williams, J.R. Large area hydrologic modeling and assessment part I: Model development 1. JAWRA J. Am. Water Resour. Assoc. 1998, 34, 73-89. [CrossRef]

34. Lyon, S.W.; Walter, M.T.; Gérard-Marchant, P.; Steenhuis, T.S. Using a topographic index to distribute variable source area runoff predicted with the SCS curve-number equation. Hydrol. Process. 2004, 18, 2757-2771. [CrossRef]

35. Mishra, S.K.; Singh, V.P. Soil Conservation Service Curve Number (SCS-CN) Methodology; Springer Science \& Business Media: Berlin, Germany, 2013; Volume 42.

36. Allen, R.G.; Jensen, M.E.; Wright, J.L.; Burman, R.D. Operational estimates of reference evapotranspiration. Agron. J. 1989, 81, 650-662. [CrossRef]

37. Monteith, J.L. Evaporation and environment. Symp. Soc. Exp. Biol. 1965, 19, 205-234. [PubMed]

38. Shi, Y.; Eberhart, R. A modified particle swarm optimizer. In Proceedings of the 1998 IEEE International Conference on Evolutionary Computation Proceedings, IEEE World Congress on Computational Intelligence, Anchorage, AK, USA, 4-9 May 1998.

39. Arnold, J.G.; Moriasi, D.N.; Gassman, P.W.; Abbaspour, K.C.; White, M.J.; Srinivasan, R.; Harmel, R.D.; van Griensven, A.; Van Liew, M.W.; Kannan, N. SWAT: Model use, calibration, and validation. Trans. ASABE 2012, 55, 1491-1508. [CrossRef]

40. Neupane, R.P.; White, J.D.; Alexander, S.E. Projected hydrologic changes in monsoon-dominated Himalaya Mountain basins with changing climate and deforestation. J. Hydrol. 2015, 525, 216-230. [CrossRef]

41. Saharia, A.M.; Sarma, A.K. Future climate change impact evaluation on hydrologic processes in the Bharalu and Basistha basins using SWAT model. Nat. Hazards 2018, 92, 1463-1488. [CrossRef]

42. Jing-Huan, T.; Cui, Q.; Xu, J.; Zhou, X. Surface -evaporation of large and middle reservoirs affects the cunount of water resource in the yellow river valley. J. Shandong Agric. Univ. 2005, 36, 391-394.

43. Nash, J.E.; Sutcliffe, J.V. River flow forecasting through conceptual models part I-A discussion of principles. J. Hydrol. 1970, 10, 282-290. [CrossRef]

44. Moriasi, D.N.; Arnold, J.G.; Van Liew, M.W.; Bingner, R.L.; Harmel, R.D.; Veith, T.L. Model evaluation guidelines for systematic quantification of accuracy in watershed simulations. Trans. ASABE 2007, 50, 885-900. [CrossRef]

45. Ling, Z.; Karthikeyan, R.; Bai, Z.; Srinivasan, R. Analysis of streamflow responses to climate variability and land use change in the Loess Plateau region of China. CATENA 2017, 154, 1-11.

46. Chen, Y.; Chen, X.; Xu, C.Y.; Zhang, M.; Liu, M.; Gao, L. Toward Improved Calibration of SWAT Using Season-Based Multi-Objective Optimization: A Case Study in the Jinjiang Basin in Southeastern China. Water Resour. Manag. 2018, 32, 1193-1207. [CrossRef]

47. Deb, K.; Pratap, A.; Agarwal, S.; Meyarivan, T.A.M.T. A fast and elitist multiobjective genetic algorithm: NSGA-II. IEEE Trans. Evol. Comput. 2002, 6, 182-197. [CrossRef]

48. Vrugt, J.A.; Gupta, H.V.; Bastidas, L.A.; Bouten, W.; Sorooshian, S. Effective and efficient algorithm for multiobjective optimization of hydrologic models. Water Resourc. Res. 2003, 39. [CrossRef]

49. Kim, H.; Lee, S. Assessment of a seasonal calibration technique using multiple objectives in rainfall-runoff analysis. Hydrol. Process. 2014, 28, 2159-2173. [CrossRef]

50. Kim, H. Potential improvement of the parameter identifiability in ungauged catchments. Water Resour. Manag. 2016, 30, 3207-3228. [CrossRef]

51. Haddeland, I.; Skaugen, T.; Lettenmaier, D. Hydrologic effects of land and water management in North America and Asia: 1700? 1992. Hydrol. Earth Syst. Sci. Discuss. 2007, 11, 1035-1045.

52. Giertz, S.; Junge, B.; Diekkrüger, B. Assessing the effects of land use change on soil physical properties and hydrological processes in the sub-humid tropical environment of West Africa. Phys. Chem. Earthparts A/B/C 2005, 30, 485-496. [CrossRef] 
53. Qiu, G.Y.; Yin, J.; Tian, F.; Geng, S. Effects of the "Conversion of Cropland to Forest and Grassland Program" on the water budget of the Jinghe River catchment in China. J. Environ. Qual. 2011, 40, 1745-1755. [CrossRef] [PubMed]

54. Jiang, G.; Gao, P.; Mu, X.; Chai, X. Effect of Conversion of Farmland to Forestland or Grassland on the Change in Runoff and Sediment in the Upper Reaches of Beiluo River. Res. Soil Water Conserv. 2015, 22, 1-6.

55. Santos, R.; Fernandes, L.S.; Pereira, M.G.; Cortes, R.M.V.; Pacheco, F.A.L. A framework model for investigating the export of phosphorus to surface waters in forested watersheds: Implications to management. Sci. Total Environ. 2015, 536, 295-305. [CrossRef] [PubMed]

56. Santos, R.; Fernandes, L.S.; Moura, J.P.; Pereira, M.G.; Pacheco, F.A.L. The impact of climate change, human interference, scale and modeling uncertainties on the estimation of aquifer properties and river flow components. J. Hydrol. 2014, 519, 1297-1314. [CrossRef]

57. Dong, N.; Yang, M.; Meng, X.; Liu, X.; Wang, Z.; Wang, H.; Yang, C. CMADS-Driven Simulation and Analysis of Reservoir Impacts on the Streamflow with a Simple Statistical Approach. Water 2019, 11, 178. [CrossRef]

(C) 2019 by the authors. Licensee MDPI, Basel, Switzerland. This article is an open access article distributed under the terms and conditions of the Creative Commons Attribution (CC BY) license (http://creativecommons.org/licenses/by/4.0/). 